\title{
Identifikasi Manajemen Kolaborasi Pengelolaan Taman Nasional Laut di Indonesia
}

\author{
Arief Khoiri Rustandi, ${ }^{1 *}$ Cecep Aminudin, ${ }^{1}$ Refial Fadly ${ }^{1}$ \\ ${ }^{1}$ ECOTAS, Cigadung Green Land A9, Bandung 40191, Indonesia
}

\begin{tabular}{ll}
\hline & Abstrak \\
Kata Kunci: & Manajemen kolaborasi taman nasional laut diharapkan dapat meningkatkan \\
Manajemen & efektivitas pengelolaan dengan melibatkan berbagai pemangku kepentingan \\
kolaborasi, taman & dalam proses pengelolaan. Kajian ini bertujuan mengidentifikasi \\
nasional laut & manajemen kolaborasi di tujuh taman nasional laut di Indonesia. Dari hasil \\
& penelitian diketahui pentingnya pelibatan pemerintah daerah dan \\
& masyarakat dalam pengelolaan taman nasional laut yang mencakup \\
& pembagian peran dan akses terhadap manfaat taman nasional laut dalam \\
& kerangka pengelolaan taman nasional laut yang menjamin kelestarian \\
& fungsinya sesuai dengan tujuan penetapannya.
\end{tabular}

Keywords:

Co-management, marine national park

\begin{abstract}
Collaborative management of marine national parks is expected to increase management effectiveness by involving various stakeholders in the management process. This study aims to identify collaborative management in seven marine national parks in Indonesia. From the research results it is known the importance of involving the local government and the community in the management of marine national park which includes the distribution of roles and access to the benefits of the marine national park within the framework of marine national park management that guarantees the preservation of its function in accordance with its stated objectives.
\end{abstract}

\section{PENDAHULUAN}

Taman Nasional adalah Kawasan Pelestarian Alam (KPA) yang mempunyai ekosistem asli, dikelola dengan sistem zonasi yang dimanfaatkan untuk tujuan penelitian, ilmu pengetahuan, pendidikan, menunjang budidaya, pariwisata, dan rekreasi (Republik Indonesia 2011; 1990).

Istilah Taman Nasional Laut (TNL) dapat ditemukan dalam Undang-Undang Nomor 1 Tahun 2014 Tentang Perubahan Atas Undang-Undang Nomor 27 Tahun 2007
Tentang Pengelolaan Wilayah Pesisir dan Pulau-Pulau Kecil. Menurut penjelasan Angka 22 Pasal 78A Undang-Undang tersebut, yang dimaksud dengan "kawasan konservasi di wilayah pesisir dan pulau-pulau kecil" termasuk Kawasan Suaka Alam dan Kawasan Pelestarian Alam yang berada di wilayah pesisir dan pulau-pulau kecil, dalam bentuk Taman Nasional atau Taman Nasional Laut, Suaka Margasatwa Laut, Suaka Alam Laut, Taman Wisata Laut, dan Cagar Alam Laut, antara lain: (a) Taman Nasional (Laut) Kepulauan Seribu; (b) Taman Nasional

\footnotetext{
*Penulis koresponden: arief.khoiri.rustandi@ecotas.org
} 
Kepulauan Karimunjawa; (c) Taman Nasional (Laut) Bunaken; (d) Taman Nasional (Laut) Kepulauan Wakatobi; (e) Taman Nasional (Laut) Taka Bonerate; (f) Taman Nasional Teluk Cenderawasih; dan (g) Taman Nasional Kepulauan Togean (Republik Indonesia 2007).

Pendekatan manajemen kolaboratif ( $\mathrm{Co}$ management) dalam pengelolaan kawasan konservasi sudah lama dipromosikan oleh berbagai pihak. Pendekatan co-management merupakan sebuah kerangka kerja yang menggambarkan suatu situasi di mana satu atau lebih aktor sosial menegosiasikan, mendefinisikan dan menyepakati diantara mereka sendiri perihal pembagian peran dan tanggung jawab pengelolaan suatu kawasan sumberdaya tertentu serta menjamin adanya pembagian manfaat yang adil atas sumberdaya tersebut (Borrini-Feyerabend, G, dkk. 2007 dalam Santosa dan Setyowati (2016)).

Menurut Peraturan Menteri Kehutanan (Permenhut) No. 19/2004, kolaborasi pengelolaan Kawasan Suaka Alam (KSA) dan KPA adalah "pelaksanaan suatu kegiatan atau penanganan suatu masalah dalam rangka membantu meningkatkan efektivitas pengelolaan KSA dan KPA secara bersama dan sinergis oleh para pihak atas dasar kesepahaman dan kesepakatan bersama sesuai dengan peraturan perundang-undangan yang berlaku" (Menteri Kehutanan 2004).

Permenhut 85/2014 terbit dan mencabut Permenhut 19/2004. Menurut Permenhut 85/2014, kerjasama penyelenggaraan KSA dan KPA adalah kegiatan bersama para pihak yang dibangun atas kepentingan bersama untuk optimalisasi dan efektifitas pengelolaan kawasan atau karena adanya pertimbangan khusus bagi penguatan ketahanan nasional. Kerjasama bertujuan untuk mewujudkan penguatan tata kelola pengelolaan kawasan dan konservasi keanekaragaman hayati. Kerjasama dapat meliputi penguatan fungsi KSA dan KPA serta konservasi keanekaragaman hayati dan pembangunan strategis yang tidak dapat dielakkan (Menteri Kehutanan 2014).

Kawasan konservasi di bawah kewenangan Kementerian Kehutanan dikelompokkan sebagai KPA dan KSA. KPA yang mencakup wilayah perairan adalah Taman Nasional Laut (TNL) dan Taman Wisata Alam Laut (TWAL). Sedangkan KSA yang mencakup wilayah perairan adalah Suaka Margasatwa Laut (SML) dan Cagar Alam Laut (CAL). KPA terdiri dari 7 (tujuh) Taman
Nasional Laut dengan luas keseluruhan 4.043.541,30 Ha, dan 14 Taman Wisata Alam Laut dengan luas keseluruhan 491.248,00 Ha. Adapun KSA terdiri dari 5 (lima) Suaka Margasatwa Laut dengan luas keseluruhan 5.678,25 Ha, dan 6 (enam) Cagar Alam Laut dengan luas keseluruhan 154.480,00 Ha. Kawasan konservasi laut yang terakhir diinisiasi dan ditetapkan oleh Kementerian Kehutanan adalah Taman Nasional Laut Kepulauan Togean pada tahun 2004 (Direktorat Konservasi Kawasan dan Jenis Ikan 2013).

Tabel 1 berikut ini menunjukkan tujuh Taman Nasional Laut di Indonesia berikut luasannya masing-masing.

Tabel 1. Taman Nasional Laut (TNL) di Indonesia

\begin{tabular}{|l|l|l|r|}
\hline No & \multicolumn{1}{|c|}{ PROVINSI } & \multicolumn{1}{|c|}{ NAMA } & LUAS (HA) \\
\hline 1 & Sulawesi Utara & TN Laut Bunaken & $89.065,00$ \\
\hline 2 & $\begin{array}{l}\text { Sulawesi } \\
\text { Selatan }\end{array}$ & $\begin{array}{l}\text { TN Laut Taka } \\
\text { Bone Rate }\end{array}$ & $530.765,00$ \\
\hline 3 & Papua & $\begin{array}{l}\text { TN Laut Teluk } \\
\text { Cendrawasih }\end{array}$ & $1.453 .500,00$ \\
\hline 4 & DKI Jakarta & $\begin{array}{l}\text { TN Laut } \\
\text { Kepulauan Seribu }\end{array}$ & $107.489,00$ \\
\hline 5 & $\begin{array}{l}\text { Sulawesi } \\
\text { Tenggara }\end{array}$ & $\begin{array}{l}\text { TN Laut } \\
\text { Wakatobi }\end{array}$ & $1.390 .000,00$ \\
\hline 6 & Jawa Tengah & $\begin{array}{l}\text { TN Laut } \\
\text { Karimunjawa }\end{array}$ & $110.117,30$ \\
\hline 7 & $\begin{array}{l}\text { Sulawesi } \\
\text { Tengah }\end{array}$ & $\begin{array}{l}\text { TN Laut } \\
\text { Kepulauan } \\
\text { Togean }\end{array}$ & $362.605,00$ \\
\hline & T O T A L & $4.043 .541,30$ \\
\hline
\end{tabular}

Sumber: Kemenhut (2004) dalam Direktorat Konservasi Kawasan dan Jenis Ikan (2013)

Artikel ini bertujuan untuk mengindentifikasi manajemen kolaborasi dalam pengelolaan taman nasional laut di Indonesia.

\section{METODE PENELITIAN}

Penelitian ini merupakan penelitian yang bersifat deskriptif dengan menggunakan pendekatan kualitatif dengan menggunakan data sekunder berupa bahan pustaka yang relevan dengan topik kajian. 


\section{HASIL DAN PEMBAHASAN}

\subsection{Taman Nasional Laut Bunaken}

Taman Nasional Bunaken (TNB) ditetapkan berdasarkan Surat Keputusan (SK) Menhut No. 730/Kpts-11/1991 yang merupakan penggabungan dari dua fungsi, yaitu taman wisata laut Bunaken (ditetapkan Pemda Sulawesi Utara pada tahun 1980) dan cagar alam laut Manado Tua (ditetapkan Menhut pada tahun 1986). Permasalahan pengelolaan TNB antara lain penangkapan ikan yang bersifat destruktif, dan masyarakat belum merasakan keuntungan dari keberadaan taman nasional. Pada tahun 1998 dimulai proses optimalisasi pengelolaan dengan memperkuat peran stakeholders melalui mekanisme comanagement dengan inisiasi Natural resources Management (NRM) (Alikodra dkk. 2008).

Pengelolaan TNB menurut Peraturan Daerah Propinsi Sulawesi Utara Nomor 14 Tahun 2000 tentang Pungutan Masuk Pada Kawasan TNB dilakukan oleh Balai TNB/Instansi sesuai dengan tugas pokok dan fungsinya dalam mengelola kawasan dimaksud. Untuk membantu tugas-tugas Balai TNB dalam melestarikan TNB, dibentuk Dewan Pengelolaan TNB yang susunan keanggotaan dan tugasnya ditetapkan oleh Gubernur. Dewan Pengelolaan TNB merupakan forum bersama antara instansi Pemerintah terkait, Lembaga Swadaya Masyarakat (LSM), sektor bisnis dan akademisi untuk bekerjasama memperkuat pengelolaan TNB sehingga dapat memberikan manfaat secara berlanjut, baik untuk saat ini maupun untuk masa yang akan datang (Sulawesi Utara 2000).

Hasil penerimaan pungutan masuk TNB dibagi antara Pemerintah Pusat, Propinsi dan Kabupaten/Kota, dan Dewan Pengelolaan TNB dengan perimbangan sebagai berikut: (a) sebesar $5 \%$ (lima perseratus) untuk Pemerintah Pusat; (b). Sebesar $15 \%$ (lima belas perseratus) untuk Pemerintah Propinsi dan Kabupaten/Kota; (c). Sebesar $80 \%$ (delapan puluh perseratus) untuk Dewan Pengelolaan Taman Nasional Bunaken (Sulawesi Utara 2000).

Dalam pelaksanaannya muncul berbagai kritikan terhadap kinerja DPTNB tentang penyaluran dana bagi hasil, Dewan Pengelola yang kurang aspiratif dan potensial berpraktek kolusi; serta Forum Masyarakat Peduli TNB yang belum mampu bertugas secara efektif (BTNB 2006 dalam Alikodra dkk. 2008). Sehingga ada wacana dari Pemkot Manado untuk mengambilalih pengelolaan TNB supaya Pendapatan Asli Daerah (PAD) meningkat (Alikodra dkk. 2008).

\subsection{Taman Nasional Laut Taka Bonerate}

Kawasan Taman Nasional Laut Taka Bonerate (TNTBR) ditetapkan dengan SK Menteri Kehutanan Nomor 92/KPTS-II/2001 tanggal 15 Maret 2001 dengan luas kawasan 530.765 Ha. merupakan karang atol terbesar ketiga di dunia, yang luasannya mencapai 220.000 Ha, setelah Atol Kwajifein di Kepulauan Marshall dan Atol Suvadiva di Maldive, serta memiliki keanekaragaman biota laut yang tinggi dan habitat bagi berbagai spesies satwa laut yang langka dan dilindungi (Direktorat Jenderal Konservasi Sumber Daya Alam dan Ekosistem 2019).

Meski secara umum, upaya pengelolaan telah berjalan cukup baik dengan mulai terlihatnya pengelolaan sumberdaya Kawasan atau sosial ekonomi, namun masih perlu dilakukan percepatan (pengembangan) upaya pengelolaan dan kemungkinan perbedaan sudut pandang (perspektif) pengelolaan yang tidak sama (Direktorat Konservasi Kawasan dan Jenis Ikan 2015).

Taman Nasional sekaligus Cagar Biosfer Dunia Taka Bonerate di Sulawesi Selatan ini termasyhur karena gugusan atol di dalamnya merupakan atol terluas ketiga di dunia. Keindahan bawah laut Taman Nasional ini ditunjang oleh keberadaan gugusan atol dan terumbu karang yang ada di dasar laut. Praktik perikanan yang tidak lestari menyebabkan kerusakan banyak terumbu karang di dalam taman nasional. Balai TNTB tertarik mengadopsi metode metode baru yang dikembangkan oleh PT Mars di Pulau Badi seiring dengan perkembangan rehabilitasi terumbu karang. Metode Mars Accelerated Reef Rehabilitation System (MARRS) mencakup aspek perencanaan, kajian lokasi, dan intensitas pemantauan, serta aspek teknis, seperti penggunaan struktur laba-laba. Dalam implementasinya, masyarakat turut terlibat secara aktif dalam upaya transplantasi terumbu karang Taka Bonerate secara berkelanjutan (Wahju Rudianto dkk. 2017). 


\subsection{Taman Nasional Laut Teluk Cendrawasih}

Taman Nasional Laut Teluk Cendrawasih ditetapkan berdasarkan Surat Keputusan Menteri Kehutanan No. 8009/KptsII/2002 tanggal 29 Agustus 2002 dengan luas 1.453.00 ha. Balai Taman Nasional Teluk Cendrawasih telah bekerjasama dengan sejumlah pihak dalam mengelola Teluk Cendrawasih antara lain dengan Universitas Negeri Papua, Pemerintah Daerah Kabupaten Teluk Wondama, World Wide Fund (WWF) Region Sahul Papua, The Nature Conservancy, Conservation International dan Southeast Asian Regional Centre for Tropical Biology (SEAMEO BIOTROP) (Direktorat Konservasi dan Keanekaragaman Hayati Laut 2020d).

Transformasi peran kelembagaan pengelolaan taman nasional di Papua dari government based management menjadi collaborative management telah berjalan terutama setelah dikeluarkannya perundangan tentang sistem pengelolaan kolaborasi yaitu Permenhut No. P.19/Menhut-II/2004 tentang kolaborasi dalam pengelolaan kawasan suaka alam dan kawasan pelestarian alam. Penerapan sebuah sistem pengelolaan yang baru dan melibatkan banyak pihak dengan berbagai kepentingan menjadi tantangan tersendiri, sehingga kajian penerapan sistem kolaborasi berbasis potensi pemangku kepentingan dalam pengelolaan taman nasional di Papua sangat penting sebagai pembelajaran dan perbaikan pengelolaan taman nasional ke depan (Winara dan Mukhtar 2011).

Membangun kolaborasi dalam pengelolaan Taman Nasional Teluk Cenderawasih menurut Winara dan Mukhtar (2011), dapat dilakukan melalui beberapa langkah antara lain: (1) Membangun kesamaan pandangan berkolaborasi dari para pemangku kepentingan, (2) Membangun kelembagaan kolaborasi yang kuat termasuk nota kesepahaman dan kesepakatan kerja kolaborasi dari semua pihak yang terlibat, (3) Membangun iklim kolaborasi yang kondusif, (4) Menghadirkan pihak yang mampu menjadi inisiator dalam mengawal proses kolaborasi.

\subsection{Taman Nasional Laut Kepulauan Seribu (TNKpS)}

Taman Nasional Laut Kepulauan Seribu ditetapkan berdasarkan SK Menteri Kehutanan
Nomor 6310/Kpts-II/2002 yang secara administratif kawasan TNKpS berada dalam wilayah Kabupaten Administrasi Kepulauan Seribu, terletak di Kecamatan Kepulauan Seribu Utara, tepatnya di tiga kelurahan yaitu Pulau Panggang, Pulau Kelapa, dan Pulau Harapan (Direktorat Konservasi dan Keanekaragaman Hayati Laut 2020b).

Menurut Prabowo, Arief, dan Sunarminto (2015), kolaborasi di TNKpS belum terjadi, sejauh ini yang terjadi sebatas kerjasama. Menurut mereka, tujuan para pihak sudah sesuai dengan rencana pengelolaan TNKpS, namun 11 dari 15 program Rencana Pengelolaan Taman Nasional (RPTN) yang belum terkordinasikan dengan baik. Penyelesaianya adalah dengan berkolaborasi dengan pihak yang memiliki tujuan yang sesuai. Karena tujuan pengelolaan para pihak dapat menjadi acuan penting penentuan alokasi kolaborasi yang tepat.

Menurut Sambali dkk. (2014), strategi yang dapat dikembangkan dalam pengelolaan TNKpS yaitu:

1. Peninjauan dan revisi Undang-undang Nomor 32 Tahun 2004 tentang Pemerintahan Daerah dan Undang-undang Nomor 5 Tahun 1990 tentang Konservasi Sumber Daya Alam Hayati dan Ekosistemnya. Substansi yang perlu direvisi adalah pasal 17 dan 18 dalam UU Nomor 32 Tahun 2004 belum mengakomodir kegiatan perikanan dan lebih menitikberatkan pada pengelolaan sumber daya laut, sementara UU Nomor 5 Tahun 1990 lebih terfokus pada konservasi kehutanan/wilayah daratan dan belum mengatur pengelolaan konservasi pesisir dan laut.

2. Peninjauan dan revisi Peraturan Daerah DKI Jakarta Nomor 1 Tahun 2012 pasal 186 yang hanya melarang penambangan pasir laut, sementara Rencana Pengelolaan Taman Nasional Kepulauan Seribu Tahun 1999 - 2019 melarang penambangan pasir dan batu karang.

3. Pemanfaatan kawasan perairan dalam kawasan Taman Nasional oleh kegiatan masyarakat maupun pemangku kepentingan lainnya harus ditujukan untuk menunjang fungsi kawasan.

4. Pengawasan dan Pengendalian penambangan karang dan pasir disertai dengan pengadaan material batu dan pasir 
melalui kebijakan subsidi oleh pemerintah daerah.

5. Pendidikan dan keterampilan masyarakat dalam kawasan konservasi ditingkatkan disertai upaya pengembangan mata pencaharian alternatif bagi masyarakat.

6. Kolaborasi dalam pengelolaan sumber daya hayati antara pemerintah daerah dan BTNKpS.

\subsection{Taman Nasional Laut Wakatobi}

Taman Nasional Laut Wakatobi ditetapkan berdasarkan SK Menteri Kehutanan Nomor 393/Kpts-V/1996. Taman Nasional Laut dengan luas areanya mencapai 1.390 .000 ha tersebut sangat terkenal di dunia karena kekayaan jenis terumbu karangnya. Wakatobi merupakan kependekan dari nama empat pulau besar yang ada di kawasan tersebut, yaitu Pulau Wangi-wangi, Pulau Kaledupa, Pulau Tomia dan Pulau Binongko. Keanekaragaman jenisnya melebihi jenis terumbu karang di laut Karibia (50 jenis) dan Laut Merah di Mesir (300 jenis). Secara umum perairan lautnya mempunyai konfigurasi dari mulai datar sampai melandai kearah laut, dan beberapa daerah perairan terdapat yang bertubir curam. Kedalaman airnya bervariasi, bagian terdalam mencapai 1.044 meter dengan dasar perairan sebagian besar berpasir dan berkarang (Direktorat Konservasi dan Keanekaragaman Hayati Laut 2020e).

Berdasarkan hasil penelitian Sopari, Oka, dan Salman (2014) terdapat delapan sumber daya penting yang dikelola oleh Balai TN Wakatobi dan Pemerintah Kabupaten Wakatobi dan masih terdapat berbagai macam permasalahan dalam pengelolaan sumberdaya tersebut seperti illegal fishing, destructive fishing, penambangan pasir, belum sinergisnya pengelolaan (pengunjung, perizinan usaha perikanan dan perizinan pariwisata), serta keterbatasan sumber daya. Permasalahan yang ada perlu dipecahkan secara bersama-sama oleh Balai TN Wakatobi dan Pemerintah Kabupaten Wakatobi sebagai pengelola kawasan, oleh karena itu diperlukan kolaborasi perencanaan sebagai salah satu alternatif solusi. Kontribusi dan arah perencanaan kedua pihak pun mendukung untuk kolaborasi perencanaan pengelolaan sumber daya alam hayati secara lestari karena masih mengakomodir kegiatankegiatan konservasi. Model kolaborasi perencanaan yang dapat didesain untuk memecahkan berbagai persoalan yang merupakan saran/rekomendasi dari penelitian mereka yaitu model kolaborasi perencanaan penanganan kasus, patroli/operasi pengamanan, penyuluhan/sosialisasi peraturan, monitoring delapan sumberdaya penting/target konservasi, rehabilitasi sumber daya alam hayati, pengelolaan pengunjung, pengelolaan izin usaha perikanan dan pengembangan serta perizinan pariwisata alam.

\subsection{Taman Nasional Laut Karimunjawa (TNKJ)}

Pulau Karimunjawa dengan ekosistem hutan hujan tropis dataran rendah seluas $1.285,50$ ha, dan wilayah perairan $110.117,30$ ha, yang telah ditetapkan sebagai kawasan pelestarian alam (KPA) berdasarkan Surat Keputusan Menhut No. 74/Kpts-II/2001 tanggal 15 Maret 2001 (Direktorat Konservasi dan Keanekaragaman Hayati Laut 2020a).

Taman Nasional Karimunjawa (TNKJ) merupakan salah satu kawasan konservasi laut yang mendapat prioritas pengelolaan secara nasional karena luasan dan potensi keanekaragaman hayati yang dimiliki, namun keutuhannya terancam dengan kegiatan eksploitasi penangkapan yang cenderung merusak dan pengembangan pariwisata yang tidak terkontrol. Menurut Alikodra dkk. (2008), permasalahan pengelolaan TNKJ disebabkan oleh keterbatasan kapasitas pengelolaan, kurangnya dukungan dinas teknis terkait dan partisipasi masyarakat dalam usaha konservasi dan lemahnya koordinasi. Sejalan dengan otonomi daerah telah berkembang konsep comanagement dalam pengelolaan kawasan konservasi, akan tetapi penerapannya belum sepenuhnya menggunakan prinsip-prinsip comanagement.

\subsection{Taman Nasional Laut Kepulauan Togean}

Taman Nasional Laut Kepulauan Togean yang terletak di Provinsi Sulawesi Tengah, ditetapkan sebagai Taman Nasional Laut berdasarkan SK. Menhut Nomor: Sk.418/Menhut-Ii/2004; Tgl. 19-10-2004. Taman Nasional Laut ini memiliki luas kawasan 362,605.00 dengan kategori II menurut International Union for Conservation of Nature (IUCN). Kepulauan ini dikenal kaya 
akan terumbu karang dan berbagai biota laut yang langka dan dilindungi (Direktorat Konservasi dan Keanekaragaman Hayati Laut 2020c).

Penelitian Sangadji dkk. (2011) mengungkapkan, faktor-faktor yang dapat meningkatkan partisipasi masyarakat dalam pengelolaan TNLKT adalah kapasitas diri masyarakat melalui peningkatan efektivitas proses penyuluhan. Proses penyuluhan menjadi kunci peningkatan partisipasi apabila diikuti dengan kebijakan penerapan konsep kolaborasi dalam pengelolaan TNLKT secara konsisten. Strategi yang dapat digunakan adalah meningkatkan proses penyuluhan yang partisipatif yang memungkinkan masyarakat ikut serta dalam proses pengambilan keputusan berkaitan dengan pengelolaan TNLKT. Menurut mereka, kejelasan status dan penerapan konsep kolaboratif dalam pengelolaan TNLKT oleh pemerintah dengan pendekatan penyuluhan partisipatif perlu segera dilakukan. Partisipasi masyarakat dalam konservasi perlu didorong sebagai bentuk pengakuan (recognition) serta karena ketergantungan hidup mereka pada sumber daya alam di sekitarnya. Mekanisme yang menjamin akses masyarakat terhadap sumberdaya atau kompensasi atas akses mereka yang terhambat juga diperlukan.

\section{PENUTUP}

Manajemen kolaborasi dalam pengelolaan taman nasional laut memerlukan kerjasama antara otoritas pengelola taman nasional dengan pemerintah daerah serta peningkatan partisipasi masyarakat yang dapat dilakukan dengan penyuluhan partisipatif yang juga berkaitan dengan akses terhadap sumber daya alam dalam pengelolaan taman nasional laut yang lestari dan berkelanjutan. Kolaborasi pengelolaan taman nasional laut yang teridentifikasi antara lain melalui pembentukan dewan pengelolaan taman nasional yang beranggotakan unsur pemerintah dan non pemerintah termasuk masyarakat, universitas dan Lembaga Swadaya Masyarakat yang dapat berkolaborasi dalam perencanaan, pelaksanaan, pengawasan dan pemantauan dalam pengelolaan taman nasional laut.

\section{DAFTAR PUSTAKA}

Alikodra, Hadi S., Dedi Soedharma, Sambas Basuni, dan Purwanti Frida. 2008. "Konsep Co-Management Taman Nasional Karimunjawa." Bogor: IPB (Bogor Agricultural University).

Direktorat Jenderal Konservasi Sumber Daya Alam dan Ekosistem. 2019. Zonasi Baru Taman Nasional Taka Bonerate. Jakarta: Kementerian Lingkungan Hidup dan Kehutanan.

Direktorat Konservasi dan Keanekaragaman Hayati Laut. 2020a. "Data Kawasan Konservasi Taman Nasional Laut Karimun Jawa." 2020. http://kkji.kp3k.kkp.go.id/index.php/ba sisdata-kawasankonservasi/details/1/13.

2020b. "Data Kawasan Konservasi Taman Nasional Laut Kepulauan Seribu." 2020. http://kkji.kp3k.kkp.go.id/index.php/ba sisdata-kawasankonservasi/details/1/11.

2020c. "Data Kawasan Konservasi Taman Nasional Laut Kepulauan Togean." 2020. http://kkji.kp3k.kkp.go.id/index.php/ba sisdata-kawasan-

konservasi/details/1/14.

2020d. "Data Kawasan Konservasi

Taman Nasional Laut Teluk Cendrawasih.” 2020. http://kkji.kp3k.kkp.go.id/index.php/ba sisdata-kawasankonservasi/details/1/10.

2020e. "Data Kawasan Konservasi Taman Nasional Laut Wakatobi." 2020.

http://kkji.kp3k.kkp.go.id/index.php/ba sisdata-kawasan-

konservasi/details/1/12.

Direktorat Konservasi Kawasan dan Jenis Ikan. 2013. Informasi Kawasan Konservasi Perairan di Indonesia. Jakarta: Direktorat Jenderal Kelautan, Pesisir, dan Pulau-pulau Kecil, Kementerian Kelautan dan Perikanan.

2015. Profil Kawasan Konservasi Sulawesi Selatan. Jakarta: Kementerian Kelautan dan Perikanan.

Menteri Kehutanan. 2004. Peraturan Menteri Kehutanan Nomor: P.19/MenhutII/2004 tentang Kolaborasi 
Pengelolaan Kawasan Suaka Alam Dan Kawasan Pelestarian Alam. 2014. Peraturan Menteri Kehutanan Nomor P.85/Menhut-II/2014 tentang tata Cara Kerjasama Penyelenggaraan Kawasan Suaka Alam dan Kawasan Pelestarian Alam.

Prabowo, Eka Dana, Harnios Arief, dan Tutut Sunarminto. $2015 . \quad$ "Analisis Manajemen Kolaboratif Dalam Pengelolaan Taman Nasional Laut Kepulauan Seribu (TNKpS)." Tesis, Bogor: Institut Pertanian Bogor.

Republik Indonesia. 1990. Undang-Undang Nomor 5 Tahun 1990 tentang Konservasi Sumber Daya Alam Hayati dan Ekosistemnya. Lembaran Negara Tahun 1990 Nomor 49, Tambahan Lembaran Negara Nomor 3419. 2007. Undang-Undang Nomor 1 Tahun 2014 Tentang Perubahan Atas Undang-Undang Nomor 27 Tahun 2007 Tentang Pengelolaan Wilayah Pesisir dan Pulau-Pulau Kecil.

. 2011. Peraturan Pemerintah Nomor 28 Tahun 2011 Tentang Pengelolaan Kawasan Suaka Alam Dan Kawasan Pelestarian Alam.

Sambali, Hariyani, Fredinan Yulianda, Dietriech G Bengen, dan M. Mukhlis Kamal. 2014. "Analisis Kelembagaan Pengelola Taman Nasional Laut Kepulauan Seribu." Jurnal Sosial Ekonomi Kelautan dan Perikanan 9 (1).

Sangadji, Muhd Nur, Sumardjo, Pang S Asngari, dan Soenarmo. 2011. "Strategi Penyuluhan di Kawasan Konservasi (Kasus Taman Nasional Kepulauan Togean).” Jurnal Penyuluhan 7 (2).

Santosa, Andri, dan Abidah B. Setyowati. 2016. "Pengelolaan Kawasan Konservasi Secara Kolaboratif." Lestari Paper No. 01. Jakarta: LESTARI.

Sopari, Hery, Ngakan Putu Oka, dan Darmawan Salman. 2014. "Model Kolaborasi Perencanaan Antara Balai Taman Nasional Wakatobi dan Pemerintah Kabupaten Wakatobi Dalam Pengelolaan Sumber Daya Alam Hayati Secara Lestari." Jurnal Sains \& Teknologi 14 (2).
Sulawesi Utara. 2000. Peraturan Daerah Propinsi Sulawesi Utara Nomor 14 Tahun 2000 Tentang Pungutan Masuk Pada Kawasan Taman Nasional Bunaken.

Wahju Rudianto dkk., ed. 2017. Belajar dari Lapangan Kisah Keberhasilan Pemulihan Ekosistem di Kawasan Suaka Alam dan Kawasan Pelestarian Alam secara Partisipatif. Jakarta: Direktorat Kawasan Konservasi.

Winara, Aji, dan Abdullah Syarif Mukhtar. 2011. "Potensi Kolaborasi dalam Pengelolaan Taman Nasional Teluk Cenderawasih Di Papua." Jurnal Penelitian Hutan dan Konservasi Alam 8 (3). 